\title{
THE INFLUENCE OF LEARNING APPROACHES IN SOCCER LEARNING TOWARD PHYSICAL FITNESS OF SPORT SENIOR HIGH SCHOOL STUDENTS IN RIAU
}

\author{
Ricky Fernando ${ }^{1}$, Kamarudin ${ }^{2}$, Alfi Candra ${ }^{3}$, Pratiwi Mutiq ${ }^{4}$ \\ ${ }^{1234}$ FKIP Universitas Islam Riau, Pekanbaru \\ 1ernandoricky@edu.uir.ac.id, ${ }^{2}$ kamarudin@edu.uir.ac.id, ${ }^{3}$ alficandra@edu.uir.ac.id
}

\begin{abstract}
This study discusses the influence of tactical learning approaches in soccer learning on physical fitness of Sport Senior High School students in Riau. The purpose of this study is to determine the physical fitness that is applied through a tactical learning approach and through a technical approach in soccer learning. The method used in this study is an experimental method. The population in this study were 109 male students of Sport Senior High School in Riau. The number of samples which 30 students was divided by two cells using cluster random sampling. The study was taken for 4 months, which the number of treatments is 16 meetings with a frequency of 3 times a week. The instrument chosen by the author was a physical fitness test. The results of data analysis showed that based on the calculated value and analysis of the calculated t-value obtained, the calculated t-value obtained was greater than $t$-table at the confidence level $\alpha=0.05$ with $d f(n 1+n 2-2)=28$, where $t$-value $(1-1 / 2$ @ in the distribution list, the value of $t$ table is 1.97. Since t-value is greater than t-table 1.761, it can be concluded: (1) The learning approach using tactical approach in soccer learning had an influence on the physical fitness of students of Sport Senior High School in Riau; 2) The learning approach using technical approach in soccer learning had an influence on physical fitness students of Sport Senior High School in Riau. (3) The learning approach using the tactical approach and the technical approach in soccer learning had the same effect on the physical fitness of Sport Senior High School students in Riau. However, the learning approach using the tactical approach gave more significant influence than the technical learning approach in soccer learning.
\end{abstract}

Keywords: tactical and technical learning approaches, physical fitness, soccer learning

\section{PENGARUH PENDEKATAN PEMBELAJARAN DALAM PEMBELAJARAN SEPAKBOLA TERHADAP KEBUGARAN JASMANI SISWA SMAN OLAHRAGA PROVINSI RIAU}

\begin{abstract}
ABSTRAK
Penelitian ini membahas membahas tentang pengaruh pendekatan pembelajaran taktis dalam pembelajaran sepakbola terhadap kebugaran jasmani siswa SMAN olahraga provinsi riau. Tujuan penelitian ini adalah untuk mengetahui kebugaran jasmani yang diterapkan melalui pendekatan pembelajaran taktis dan melalui pendekatan teknis.dalam pembelajaran sepakbola.Metode yang digunakan dalam penelitian ini adalah metode eksperimen. Populasi dalam penelitian ini adalah siswa putra sman olahraga provinsi riau sebanyak 109 orang. Jumlah sampel sebanyak 30 orang dibagi dua sel dengan teknik pengambilan sampel menggunakan Cluster Random Sampling. Waktu penelitian yaitu selama 4 bulan, jumlah perlakuan 16 kali pertemuan, dengan frekuensi 1 minggu 3 kali. Instrumen yang dipilih penulis adalah tes kebugaran jasmani bagi siswa sman olahraga provinsi riau. Berdasarkan hasil analisis data bahwa berdasarkan nilai perhitungan dan analisis nilai t-hitung yang diperoleh maka didapat nilai t-hitung lebih besar dari t-tabel pada tingkat kepercayaan atau taraf nyata $\alpha=0.05$ dengan $\mathrm{dk}(\mathrm{n} 1+\mathrm{n} 2-2)=28$, dimana harga $\mathrm{t}(1-1 / 2 @)$ dalam daftar distribusi diperoleh harga $t$ tabel 1.97. dikarenakan nilai t-hitung lebih besar dari t table 1.761 maka dapat disimpulkan: (1) Pendekatan pembelajaran menggunakan pendekatan taktis dalam pembelajaran sepakbola memberikan pengaruh terhadap kebugaran jasmani siswa sman olahraga provinsi riau.2) Pendekatan pembelajaran menggunakan pendekatan teknis dalam pembelajaran sepakbola memberikan pengaruh terhadap kebugaran jasmani siswa sman olahraga provinsi riau. (3) Pendekatan pembelajaran menggunakan pendekatan taktis dan pendekatan teknis dalam pembelajaran sepakbola sama sama memberikan pengaruh terhadap kebugaran jasmani siswa sman olahraga provinsi riau., tetapi, pendekatan pembelajaran menggunakan pendekatan taktis lebih memberikan pengaruh yang signifikan dibandingkan pendekatan pembelajaran teknis dalam pembelajaran sepakbola.
\end{abstract}

Kata Kunci: pendekatan pembelajaran taktis dan teknis, kebugaran jasmani, pembelajaran sepak bola

\begin{tabular}{|c|c|c|}
\hline Submitted & Accepted & Published \\
\hline 25 Januari 2020 & 08 Mei 2020 & 27 Mei 2020 \\
\hline
\end{tabular}

\begin{tabular}{|l|c|c|c|}
\hline Citation & $:$ & $\begin{array}{c}\text { Fernando, R., Kamarudin., Candra, A., \& Mutiq, P. (2020). The Influence Of Learning Approaches In Soccer Learning } \\
\text { Toward Physical Fitness Of Sport Senior High School Students In Riau. Jurnal PAJAR (Pendidikan dan } \\
\text { Pengajaran), 4(3), 579-585. DOI : http://dx.doi.org/10.33578/pjr.v4i2.7953. }\end{array}$ \\
\hline
\end{tabular}




\section{PENDAHULUAN}

Konsep pendekatatan pembelajaran taktis memberikan solusi bagaimana mengimplementasikan keterampilan teknik ke dalam bentuk situasi permainan sebenarnya. Pembelajaran sepakbola melalui pendekatan taktis mendorong pemahaman siswa terhadap konsep bermain penerapan ketarampilan teknik dalam situasi permainan yang sebenarnya. Sasaran tujuan umum dari pembelajaran sepakbola melalui pendekatan taktis dapat meningkatkan pengajaran permainan sepakbola yang berorientasi pada minat kegembiraan memungkinkan siswa mempelajari teknik dalam konteks permainan serta pengambilan keputusan yang tepat. Melalui pendekatan pembelajaran taktis dalam pengajaran sepakbola siswa dapat mengindentifikasi masalah yang relevan sesuai dengan topik pembelajaran.

Pembelajaran sepakbola pada kenyataannya masih menganut pendekatan yang sifatnya tradisonal yang mana penekanannya pada penguasaan keterampilan dan teknik bermain sepakbola sehingga dari segi teknik dan keterampilan dapat meningkat namun secara wawasan bermain atau konsep bermain siswa tidak mampu mengaplikasikan teknik dan keterampilannya dalam bentuk permainan sebenarnya. Ketika penguasaan teknik dikuasai pengembangan aspek kognitif dan afektif diabaikan secara tidak sadar. Pada dasarnya kita mengetahui bahwa dengan rendahnya kemampuan individu akan berdampak pada rendahnya kualitas permainan, ada kesan pada siswa pendekatan semacam ini membosankan dan kurang menarik karena situasi belajar terkesan monoton. Selain itu, mahasiswa cenderung kurang mampu untuk mengimplementasikan keterkaitan anatara teknik konsep permainan. Untuk mengantisispasi iklim pembelajaran yang dilakukan oleh seorang guru harus membuat pilihan pendekatan pembelajaran yang tepat sesuai dengan karakteristik siswa, yang mana pembelajaran sepakbola memiliki karakteristik yang kompleks karena tuntutan sepakbola harus mampu mengaplikasikan keterampilan, kombinasi keterampilan, dalam penerapan taktik dan strategi permainan. Pembelajaran sepakbola dengan pendekatan teknik ini diduga dapat meningkatkan penguasaan keterampilan teknik dasar, namun ternyata banyak mendapatkan kritikan, salah satunya dikemukakan oleh Griffin, dkk, (1997) yang menyatakan bahwa keterampilan yang diajarkan sebelum subjek ajar dapat mengerti keterkaitannya dengan situasi bermain yang sesungguhnya, hasilnya dapat menghilangkan esensi dari permainan itu sendiri.Sesuai dengan kritikannya. Selain iut penelitian yang dilakukan oleh Ade Rokhayati Dkk, mengenai implementasi pendekatan taktis dalam pembelajaran penjas terhadap motivasi, kebugaran jasmani, dan kemampuan motorik, hasil penelitian menunjukkan bahwa Hasil penelitian ini menunjukkan bahwa 1) peningkatan motivasi belajar siswa yang diajar melalui pendekatan pembelajaran taktis lebih baik daripada siswa yang diajar melalui pendekatan pembelajaran konvensional, 2) peningkatan kebugaran jasmani siswa yang diajar melalui pendekatan pembelajaran taktis lebih baik dari pada siswa yang diajar melalui pendekatan pembelajaran konvensional. 3) peningkatan kemampuan motorik siswa yang diajar melalui pendekatan pembelajaran taktis lebih baik daripada siswa yang diajar melalui pendekatan pembelajaran konvensional. Berdasarkan hasil penelitian di atas bahwasanya pembelajaran yang dilakukan melalui pendekatan taktis memberikan pengaruh signifikan terhadap motivasi belajar, kebugaran jasmani, dan kemampuan motorik.

Allison and Thorpe (1997) Since the popularity of the Teaching Games For Understanding (TGfU) model has grown, there is a need to assess its effectiveness in teaching students to play games. Thus, the purpose of this study by Allison and Thorpe (1997) was to compare the effectiveness of the skill approach with that of the TGfU approach for a variety of factors; a) for the pupil these included enjoyment, the development of skill and tactical understanding and in involvement in planning and evaluation, b) for the teacher, the opportunities to observe and assess pupils. Artinya penerapan pendekatan pembelajaran taktis untuk membandingkan efektivitas pendekatan TGFU untuk berbagai factor dalam permainan hockey. Hasil penelitian menunjukkan bahwa siswa lebih 
merasakan kesenangan dalam pengembangan keterampilan pemahaman taktis keterlibatan perencanaan dan evaluasi siswa berikutnya memiliki kesempatan untuk mengamati dan menilai siswa.

Creswell, J. W. The purpose of this study was to explore the use of action research as a framework to investigate cooperative learning and tactical games as instructional models in physical education (PE). The teacher/researcher taught a tennis unit using a combination of Cooperative Learning and Teaching Games for Understanding to three classes of boys aged 11-12. Data collection included: teacher and pupil evaluations of skill, pupil reflections on the lessons, pupil interviews, teacher field journal and the documentation and course materials from the unit of work. Data analysis was conducted using inductive analysis and constant comparison (Denzin and Lincoln, 1994; Lincoln and Guba, 1985). The results of this research reinforce the concept that the implementation of any new pedagogical approach is time-consuming and highly labour intensive (Fullan, 1999). The conceptual shift the teacher/researcher made to relinquish control to students was one of the most difficult, but important, outcomes of this action research process. Artinya tujuan dari penelitian ini untuk mengekplorasi penggunaan penelitian sebagai kerangka kerja untuk menyelidiki pembelajaran kooperatif dan permainan taktis hasil penelitian ini memperkuat konsep bahwa implementasi dari setiap pendekatan memakan waktu yang cukup lama.

Smith L., Harve S., Savory L., Fairclough S., Kozub S., and Kerr C Boys (2015) in the TGM condition displayed significantly higher levels of MVPA in both rugby and football activities in comparison to the control group although no significant differences in motivation were noted post-intervention. While girls in the TGM

\section{METODE PENELITIAN}

Penelitian ini merupakan penelitian eksperimen semu (Quasi Eksperiment) jumlah populasi dalam penelitian ini adalah dalam jumlah besar dan sampel yang akan digunakan adalah condition recorded comparable PA levels in the football sessions, they recorded significantly lower PA activity levels in the netball lessons. There were no significant differences in girls' motivation post-intervention. It is recommended that future studies build on this research by continuing to examine $P A$ and the quality of student motivation while using GCAs over prolonged unit lengths (i.e. greater than 12 lessons) using structural equation modelling techniques to assess the relationships between, and mediating influences of, SDT constructs on $P A$ levels. Artinya terdapat perbedaan antara anak siswa laki-laki dan perempuan dalam penerapan pendekatan taktis siswa laki-laki lebih memiliki motivasi yang tinggi dalam permainan rugby dan sepakbola sementara siswa perempuan memiliki motivasi rendah dalam permainan rugby dan sepakbola dalam penerapan pendekatan taktis Kebugaran jasmani merupakan factor pendukung berhasil tidaknya program pembelajaran pendidikan jasmani secara utuh. Melalui pembelajaran sepakbola diharapkan siswa dapat memiliki gaya hidup aktif sehingga tercapai derajat kebugaran jasmani siswa secara sempurna. Salah satu penyebab rendahnya derajat kebugaran jasmani siswa adalah pendekatan kecabangan serta berorientasi pada prestasi individu yang diterapkan dalam pembelajaran khususnya seppakbola, dalam penerapan pembelajaran sepakbola diharapkan dapat memberikan solusi pendekatan pembelajaran yang tepat closed skill instruction atau lebih kepada kolaboratif instruksi. Sehingga mampu memodifikasi pembelajaran sepakbola untuk mencapai derajat kebugaran jasmani siswa sesuai dengan standar yang baik. Berdasarkan uraian di atas peneliti tertarik untuk membandingkan pengaruh pendekatan pembelajaran taktis dengan teknis terhadap kebugaran jasmani siswa sman olahraga provinsi riau.

seluruh subjek dalam kelompok belajar (intact group) karena sabjek dalam kelompok belajar tidak bisa dipindah-pindah maka pemilihan sampel tidak dipilih secara acak. Teknik pengambilan sampel 
yang tepat adalah Cluster Random Sampling (Maksum, 2012). Untuk menentukan kelas mana yang akan dijadikan sampel dilakukan random. Diperolehlah sampel penelitian ini adalah kelas X, XI, dan XI. Serta kelas mana yang akan mendapatkan perlakuan, pendekatan pembelajaran taktis,dan pendekatan pembelajaran teknis juga dipilih secara random.

Penelitian ini menggunakan metode Kuasi Ekperimen dengan desain Non-Equivalen Control Group Desain, yaitu variabel penelitiannya diatur secara tertib baik dengan menetapkan kontrol maupun manipulasi langsung. Peneltiannya memusatkan diri pada pengontrolan variansi karena untuk memaksimalkan variansi variabel yang berkaitan dengan hipotesis penelitian dan meminimalkan variansi variabel pengganggu yang mungkin mempengaruhi hasil eksperimen. Penelitian eksperimen dibagi menjadi dua bagian yaitu eksperimen murni dan eksperimen kuasi. Penelitian eksperimen murni mengambil subjek penelitian berupa benda atau hewan percobaan. Penelitian dilaksanakan di laboraturium yang dapat mempengaruhi hasil penelitian dikendalikan oleh peneliti. Sedangkan kuasi eksperimen atau eksperimen semu mengambil subjek penelitian pada manusia.

Kondisi lingkungan yang dapat mempengaruhi hasil penelitian tidak dapat dikendalikan oleh peneliti sehingga penelitian tidaklah murni dari eksperimen atau percobaan yang dilakukan. Penelitian kuasi eksperimen dipilih apabila peneliti ingin menerapkan sasuatu tindakan atau perlakuan. Tindakan dapat berupa model, strategi, metode, atau prosedur kerja baru untuk meningkatkan efisiensi dan efektifitas pekerjaan agar hasilnya menjadi optimal. Metode

\section{HASIL DAN PEMBAHASAN}

Pengolahan dan analisis data dalam penelitian ini berdasarkan kepada langkah-langkah yang digunakan dalam penelitian adalah metode eksperimen. Metode eksperimen menurut Arikunto (2002) adalah suatu cara penelitian "Dengan cara ini peneliti sengaja membangkitkan timbulnya suatu kejadian atau keadaan, kemudian diteliti bagaimana akibatnya". Dari uraian di atas, dapat dikatakan bahwa kegiatan percobaan (eksperimen) yang dimaksud adalah penerapan pendekatan pembelajaran taktis, dan pendekatan pembelajaran teknis.

Penelitian ini dirancang untuk mengembangkan kebugaran jasmani siswa sman olahraga provinsi riau dalam permainan sepakbola mahasiswa pada kelas yang berbeda yaitu tiga kelas dengan dua jenis perlakuan pendekatan pembelajaran. Untuk mengetahui pengaruh dan perbedaan antara 2 pendekatan pembelajaran maka dipilih desain penelitian ini adalah Nonequivalent Control Group Design. Dalam konteks penelitian ini variabel yang memberikan pengaruh (variabel bebas/independet variable) adalah pemberian dua jenis pendekatan pembelajaran sehingga dalam pelaksanaannya sampel dibagi 2 kelompok untuk memperoleh perlakuan yang berbeda-beda kelompok A mendapat perlakuan pendekatan pembelajaran taktis kelompok $\mathrm{B}$ mendapat perlakuan pendekatan pembelajaran teknis alat untuk memperoleh informasi atau mengumpulkan data dalam penelitian ini adalah tes kebugaran jasmani dalam Nurhasan dan Cholil (2007:118) yaitu Tes lari cepat 60 meter, Tes angkat tubuh (30 detik untuk putri; 60 detik untuk putra), Tes baring duduk 60 detik, Tes loncat tegak, Tes lari jauh (800 meter untuk putri; 1000 meter untuk putra) tes yang sama akan diujikan pada saat pre tets dan post tes yang telah teruji validitas dan reliabilitasnya.

penelitian yang telah penulis susun sebelumnya. 
Tabel 1. Nilai Rata-rata dan Simpangan Baku Kelompok Penelitian

Hasil Penghitungan Nilai rata-rata dan Simpangan Baku Kelompok Penelitian

\begin{tabular}{ccccc}
\hline \multirow{2}{*}{ Kelompok Penelitian } & \multicolumn{3}{c}{ Sesudah } \\
& Sebelum Eksperimen & \multicolumn{2}{c}{ Eksperimen } \\
& $\mathrm{X}$ & $\mathrm{S}$ & $\mathrm{X}$ & $\mathrm{S}$ \\
\hline Pendekatan Pembelajaran Taktis & 15.40 & 1.8 & 19.67 & 3.62 \\
Pendekatan Pembelajaran Teknis & 15.33 & 1.91 & 17.87 & 3.2 \\
\hline
\end{tabular}

Hasil Nilai rata-rata kelompok pendekatan pembelajaran taktis sebelum eksperimen di dapat nilai rata-rata sebesar 15.40 sedangkangan untuk simpangan baku di dapat nilai sebesar 1.8. Selanjutnya setelah dilakukan eksperimen di dapat nilai rata-rata sebesar 19.67 dan simpangan baku di dapat nilai sebesar 3.62. Sementara untuk kelompok pendekatan, pembelajaran teknis sebelum eksperimen di dapat nilai rata-rata sebesar 15.33, sedangkan untuk simpangan baku di dapat nilai sebesar 1.91, setelah dilakukan eksperimen melalui pendekatan pembelajan teknis di dapat nilai rata-rata 17.87 , sedangkan untuk simpangan baku didapat nilai 3.2. Setelah didapat nilai rata-rata dan simpangan baku maka selanjutnya di lakukan uji homogenitas dari kedua kelompok sampel dengan menggunakan uji kesamaan dua variansi. Hasil pengujian tersebut dapat dilihat pada table berikut ini:

Tabel 2. Hasil Uji Homogenitas Kelompok Penelitian

\begin{tabular}{cccc}
\hline \multirow{2}{*}{ Kelompok Penelitian } & \multicolumn{2}{c}{ Nilai Pengujian } & \multirow{2}{*}{ Kesimpulan } \\
\cline { 2 - 3 } & F - Hitung & F- Tabel & \\
\hline Pendekatan Pembelajaran Taktis & 0.25 & 3.89 & Homogen \\
Pendekatan Pembelajaran Teknis & 0.36 & 3.89 & Homogen \\
\hline
\end{tabular}

Dengan menggunakan derajat kebebasan dan taraf signifikan $\alpha=0.05$ pada tabel distribusi $\mathrm{F}$ di dapat $\mathrm{F}_{\text {tabel }}=3.89$, berarti $\mathrm{F}_{\text {hitung }}<\mathrm{F}_{\text {tabel }}(0.25<$ 3.89) maka dapat disimpulkan bahwa satu kelompok data berasal dari populasi yang homogen. Dengan menggunakan derajat kebebasan dan taraf signifikan $\alpha=0.05$ pada tabel distribusi $\mathrm{F}$ di dapat $\mathrm{F}_{\text {tabel }}=3.89$, berarti $\mathrm{F}_{\text {hitung }}<$ $\mathrm{F}_{\text {tabel }}(0.36<3.89)$ maka dapat disimpulkan bahwa satu kelompok data berasal dari populasi yang homogen. Setelah didapat nilai uji homogenitas pada kedua kelompok pendekatan pembelajaran maka dilakukan uji normalitas. Hasil pengujian tersebut dapat dilihat pada tabel berikut ini:

Tabel 3. Hasil Uji Normalitas Kelompok Penelitian

\begin{tabular}{cccc}
\hline \multirow{2}{*}{ Kelompok Penelitian } & \multicolumn{2}{c}{ Nilai Lo Periode Tes } & \multirow{2}{*}{ Kesimpulan } \\
& Awal & Akhir & Normal \\
\hline Pendekatan Pembelajaran Taktis & 0.18 & 0.1682 & Normal \\
Pendekatan Pembelajaran Teknis & 0.16 & 0.2133 & \\
\hline
\end{tabular}

Dari hasil analisis data yang di dapat pada uji normalitas tes awal pendekatan pembelajaran taktis diperoleh angka dengan $\mathrm{n}=15$ dan tarif nyata $\alpha=0.05$ didapat $\mathrm{L}_{\text {tabel }}=0.220$ berarti $\mathrm{L}_{\mathrm{o}}<$ $\mathrm{L}_{\text {tabel, }}$, sehingga hipotesis Nol diterima (Ha ditolak) bahwa data populasi dari mana data sampel diambil berdistribusi Normal.sedangkan untuk uji normalitas tes akhir pendekatan pembelajaran taktis diperoleh angka Dengan $\mathrm{n}=15$ dan tarif nyata $\alpha=0.05$ didapat $\mathrm{L}_{\text {tabel }}=0.220$ berarti $\mathrm{L}_{o}<$ 
Ltabel, sehingga hipotesis Nol diterima (Ha ditolak) bahwa data populasi dari mana data sampel diambil berdistribusi Normal. Selanjutnya analisis data uji normalitas tes awal pendekatan pembelajaran teknis di dapat dengan $\mathrm{n}=15$ dan tarif nyata $\alpha=0.05$ didapat $\mathrm{L}_{\text {tabel }}=0.220$ berarti $\mathrm{L}_{\mathrm{o}}<$ $\mathrm{L}_{\text {tabel, }}$, sehingga hipotesis Nol diterima (Ha ditolak) bahwa data populasi dari mana data sampel diambil berdistribusi Normal. Sedangkan untuk uji normalitas tes akhir pendekatan pembelajaran teknis didapat angka, dengan $\mathrm{n}=15$ dan tarif nyata $\alpha=0.05$ didapat $\mathrm{L}_{\text {tabel }}=0.220$ berarti $\mathrm{L}_{0}<\mathrm{L}_{\text {tabel }}$, sehingga hipotesis Nol diterima (Ha ditolak) bahwa data populasi dari mana data sampel diambil berdistribusi Normal. Berdasarkan nilai perhitungan dan analisis nilai $t_{\text {-hitung }}$ yang diperoleh maka didapat nilai $\mathrm{t}_{\text {-hitung }}$ lebih besar dari $\mathrm{t}$-tabel pada tingkat kepercayaan atau taraf nyata $\alpha=0.05$ dengan $\mathrm{dk}(\mathrm{n} 1+\mathrm{n} 2-2)=28$, dimana harga $\mathrm{t}(1-$ 1/2@) dalam daftar distribusi diperoleh harga $t$ table 1.97. dikarenakan nilai t-hitung lebih besar dari t table 1.761. maka hasil tersebut signifikan jadi terdapat perbedaan pengaruh Antara pendekatan taktis dan teknis dalam pembelajaran sepakbola terhadap kebugaran jasmani, namun pendekatan taktis lebih baik dibandingkan pendekatan pembelajaran teknis terhadap kebugaran jasmani dalam pembelajaran sepakbola

Tabel. 4. Uji Signifikasi Perbedaan Rata-rata Peningkatan Hasil Kedua Kelompok Penelitian

\begin{tabular}{cccccc} 
Kelompok Penelitian & $\mathrm{X}$ & $\mathrm{S}^{2}$ & $\begin{array}{c}\text { Nilai T- } \\
\text { Hitung }\end{array}$ & $\begin{array}{c}\text { Nilai T- } \\
\text { Tabel }\end{array}$ & Kesimpulan \\
\hline Pendekatan Pembelajaran Taktis & 19.67 & 13.1 & 3.57 & 1.761 & Signifikan \\
Pendekatan Pembelajaran Teknis & 17.87 & 10.24 & 1.97 & 1.761 & \\
\hline
\end{tabular}

Dari hasil analisis data yang di dapat pada uji perbedaan rata-rata peningkatan hasil kedua kelompok penelitian maka didapat Keterangan: jika $t_{\text {hitung }}>\mathrm{t}_{\text {tabel}}$, maka $\mathrm{H}_{\mathrm{a}}$ diterima (Terdapat pengaruh yang signifikan antara Latihan Pendekatan Teknis terhadap Kebugaran Jasmani Siswa SMA Olahraga terbukti $\left(\mathrm{t}_{\text {hitung }}>\mathrm{t}_{\text {tabel }} 3.570\right.$ $>1.761)$. Keterangan: jika $t_{\text {hitung }}>t_{\text {tabel }}$, maka $\mathrm{H}_{\mathrm{a}}$ diterima (Terdapat perbedaan pengaruh yang signifikan antara Latihan Pendekatan taktis dengan pendekatan Teknis terhadap Kebugaran Jasmani Siswa SMA Olahraga terbukti ( $t_{\text {hitung }}>t_{\text {tabel }}$ 1.97> 1.761). Berdasarkan pada penghitungan dan

\section{SIMPULAN DAN REKOMENDASI}

Berdasarkan pemaparan pada bab diatas maka dapt disimpulkan bahwa, terdapat pengaruh pendekatan pembelajaran taktis dalam pembelajaran sepakbola terhadap kebugaran jasmani pada siswa sman olahraga provinsi riau, terdapat pengaruh pendekatan pembelajaran teknis dalam pembelajaran sepakbola terhadap kebugaran jasmani pada siswa sman olahraga provinsi riau, terdapat perbedaan pengaruh antara pendekatan pembelajaran taktis dan pendekatan analisis nilai t-hitung yang diperoleh, maka didapat nilai t-hitung yang lebih besar dari. Keterangan: jika $t_{\text {hitung }}>t_{\text {tabel}}$, maka $\mathrm{H}_{\mathrm{a}}$ diterima (Terdapat perbedaan pengaruh yang signifikan antara Latihan Pendekatan taktis dengan pendekatan Teknis terhadap Kebugaran Jasmani Siswa SMA Olahraga terbukti ( $t_{\text {hitung }}>t_{\text {tabel }}$ 1,97> 1,761). Keterangan: jika $t_{\text {hitung }}>t_{\text {tabel }}$, maka $H_{a}$ diterima (Terdapat pengaruh yang signifikan antara Latihan Pendekatan Teknis terhadap Kebugaran Jasmani Siswa SMA Olahraga terbukti $\left(t_{\text {hitung }}>t_{\text {tabel }} 3,570>1,761\right)$.

pembelajaran teknis dalam pembelajaran sepakbola terhadap kebugaran jasmani pada siswa sman olahraga provinsi riau, namun pendekatan pembelajaran taktis lebih unggul dibandingkan pendekatan pembelajaran teknis terhadap kebugaran jasmani siswa sman olahraga provinsi riau.

Berdasarkan kajian ilmiah dalam penelitian tersebut sehendaknya guru dalam pembelajaran sepakbola bukan hanya menekankan 
pada keterampilan teknis namun lebih dari pada itu keterampilan teknis juga dibarengi dengan pemehaman bermain siswa di lapangan dalam

\section{DAFTAR PUSTAKA}

Alison, S., \& Thorpe, R. (1997). A Comparison of the Effectiveness of Two Approaches to Teaching Games Within Physical Education. A Skills Approach Versus a Games for Understanding Approach. The British Journal of Physical Education, 28 (3), 9-13.

Arikunto, S. (2002). Prosedur Penelitian: Suatu Pendekatan Praktek. Cetakan ke XIII, Jakarta: PT Rineka Cipta

Casey, A., \& Dyson, B. (2009). The implementation of models-based practice in physical education through action research. European Physical Education Review, 15 (2), 175-199.

Creswell, J. W. (2010). Research Design; Pendekatan Kualitatif, Kuantitatif, dan Mixed. Terjemahan Achmad Fawaid, et.al. Jogjakarta: Pustaka Pelajar

Griffin, L.L., Mitchell, S.A., \& Oslin, J.L. (1997). Teaching Sport Concept and Skills: A pembelajaran sepakbola.

Tactical Games Approach. Illionois: Champaign

Maksum, A. (2012). Metodologi Penelitian dalam Olahraga. Surabaya: Unesa University Press

Nurhasan \& Cholil. (2007). Modul Tes dan Pengukuran Keolahragaan. Bandung: FPOK. Universitas Pendidikan Indonesia

Rokhayati, A., Nur, L., Gandana, G., \& Elan, E. (2016). Implemtasi Pendekatan Taktis Dalam Pembelajaran Pendidikan Jasmani Terhadap Motivasi, Kebugaran Jasmani, dan Kemampuan Motorik. Jurnal Pendidikan Jasmani dan Olahraga, 1(2), 57-67.

Smith L., Harve S., Savory L., Fairclough S., Kozub S., \& Kerr C. (2015). Physical activity levels and motivational responses of boys and girls: A comparison of direct instruction and tactical games models of games teaching in physical education. European Physical Education Review, 21(21), 93-113. 